\title{
Evaluation of meso-substituted cationic corroles as potential antibacterial agents
}

\author{
TERESA A.F. CARDOTE ${ }^{1}$, JOANA F.B. BARATA ${ }^{1,3}$, CAROLINA AMADOR ${ }^{1}$, ELIANA \\ ALVES $S^{1,2}$, MARIA GRAÇA P.M.S. NEVES ${ }^{1}$, JOSÉ A.S. CAVALEIRO ${ }^{1}$, ÂNGELA \\ CUNHA $^{2}$, ADELAIDE ALMEIDA ${ }^{2}$ and MARIA AMPARO F. FAUSTINO ${ }^{1}$ \\ ${ }^{1}$ Química Orgânica, Produtos Naturais e Agroalimentares/QOPNA, Department \\ of Chemistry, University of Aveiro, 3810-193 Aveiro, Portugal \\ ${ }^{2}$ Centro de Estudos do Ambiente e do Mar/CESAM, Department of Biology, University of Aveiro, 3810-193 Aveiro, Portugal \\ ${ }^{3}$ CICECO (Aveiro Institute of Materials), Department of Chemistry, University of Aveiro, 3810-193 Aveiro, Portugal
}

Manuscript received on October 15, 2017; accepted for publication on December 6, 2017

\begin{abstract}
Cationicderivativesof5,10,15-tris[4-(pyridin-4-ylsulphanyl)-2,3,5,6-tetrafluorophenyl]-corrolategallium(III) pyridine and 5,10,15-tris[4-(pyridin-2-ylsulfanyl)-2,3,5,6-tetrafluorophenyl]-correlategallium(III)pyridine were synthesized and their photosensitizing properties against the naturally bioluminescent Gram-negative bacterium Allivibrio fischeri were evaluated. The cationic corrole derivatives exhibited antibacterial activity at micromolar concentrations against this Gram-negative bacterium strain.
\end{abstract}

Key words: Allivibrio fischeri, corroles, photosensitizer, PDI, bioluminescence.

\section{INTRODUCTION}

Antimicrobial photodynamic inactivation (PDI) has emerged as an alternative pathway to antibiotics in combating bacteria invasion (Jori and Brown 2004, Almeida et al. 2011, Yin et al. 2015). The goal is to use photoactive drugs (photosensitizers, PS) to trigger a series of processes leading to cells' death, after being light activated in the presence of oxygen. The basic principles are well understood. In essence,

Correspondence to: Joana F.B. Barata

E-mail: jbarata@ua.pt

Adelaide Almeida

E-mail: aalmeida@ua.pt

Maria Amparo Ferreira Faustino

E-mail: faustino@ua.pt

* Contribution to the centenary of the Brazilian Academy of Sciences. the interaction between light and the PS, generates reactive oxygen species (ROS) through either electron transfer (type I) or energy transfer (type II) reactions. These ROS will react with many cellular components that will induce oxidative processes leading to cell death (Bonnett 2000, Maisch 2009, Ergaieg et al. 2008, Tavares et al. 2011, Costa et al. 2013, Almeida et al. 2015, Wainwright et al. 2017). The great advantage of this methodology is the unlikelihood of the microorganisms to develop resistance mechanisms since there is not a particular target in the cell and also the PS don't have to accumulate in its interior to be efficient (Dahl et al. 1989, Tavares et al. 2010, Costa et al. 2011a, Preuß et al. 2013, Alves et al. 2014a).

PS with a variety of chemical structures have been used to inactivate microbial cells. 
The results obtained with macrocycles such as porphyrins, (Alves et al. 2015), phthalocyanines (Dei et al. 2006, Pereira et al. 2012, Ryskova et al. 2013, Lourenço et al. 2015, Marciel et al. 2017) or porphycenes (Xavier et al. 2010, RuizGonzález et al. 2015, Masiera et al. 2017) are particularly relevant. The discovery that positively charged PS at physiological $\mathrm{pH}$ values promote the photoinactivation of microbial cells, namely of antibiotic resistant Gram-negative bacteria has stimulated the development of new useful cationic PS for PDI. (Alves et al. 2015, Mesquita et al. 2014a, Simões et al. 2016).

Corroles are tetrapyrrolic macrocycles belonging to the porphyrinoid family, which have been calling the attention of researchers in this field, since corroles possess interesting and unique properties which confer them significant applicabilities (Aviv-Harel and Gross 2009, Teo et al. 2017). Nowadays corroles can be functionalized by several approaches (Barata et al. 2014, 2017) allowing great flexibility in the synthesis of molecules with unique physical and chemical properties. Although corroles have been investigated in several areas, their therapeutic potential has only recently been disclosed. (Lim et al. 2012, Hwang et al. 2012, Agadjanian et al. 2009, Cardote et al. 2012, Iglesias et al. 2015, Barata et al. 2013, 2015, 2016, Preuß et al. 2014, Pohl et al. 2014). According to that and following our interest in the development of tetrapyrrolic macrocycles with antibacterial activity, (Alves et al. 2009, 2014b, Carvalho et al. 2009, 2010, Costa et al. 2012, Pereira et al. 2012, Gomes et al. 2013, Mesquita et al. 2014a, b, Simões et al. 2016, Lourenço et al. 2015, Rocha et al. 2015, Batalha et al. 2015, Moura et al. 2016, Castro et al. 2017) we decided to synthesize the cationic corrole derivatives $\mathbf{2 b}$ and $\mathbf{3 b}$ and to study, for the first time, their efficiency in the PDI of Gram-negative bacteria. Herein, the synthesis, structural characterisation, photophysical properties (absorbance and singlet oxygen generation) and biological activity of the new cationic corroles against the naturally bioluminescent bacterium Allivibrio fischeri (A. fischeri) will be reported.

\section{MATERIALS AND METHODS}

Commercial reagents were used without previous purifications according to their purity (with exception of pyridine, which was previously distilled). DMSO and DMF were dried under standard procedures.

Thin layer chromatography (TLC) was used to monitor the reactions using plastified sheets coated with Silica Gel $600.2 \mathrm{~mm}$ (Merck). Purifications through preparative chromatography were performed in glass plates $(20 \times 20 \mathrm{~cm})$ previously coated with Silica Gel $600.5 \mathrm{~mm}$ and activated at $100{ }^{\circ} \mathrm{C}$ during $12 \mathrm{~h}$. Column chromatography purifications were performed with glass columns filled with Silica Gel 60 with granulometry 32-63 or 63-200 mesh.

${ }^{1} \mathrm{H}$ and ${ }^{19} \mathrm{~F}$ NMR spectra were recorded on a Bruker Avance-300 spectrometer at 300.13 and 282.38 MHz, respectively. The chemical shifts are expressed in $\delta(\mathrm{ppm})$ and the coupling constants $(J)$ in Hertz (Hz). TMS was used as internal reference for ${ }^{1} \mathrm{H}$ NMR spectra and $\mathrm{C}_{6} \mathrm{~F}_{6}$ was used as reference for the ${ }^{19} \mathrm{~F}$ NMR spectra. $\mathrm{CDCl}_{3}$ and $\mathrm{C}_{5} \mathrm{D}_{5} \mathrm{~N}$ were used as solvents for the neutral compounds, while for the cationic compounds NMR spectra were recorded with $\mathrm{CD}_{3} \mathrm{OD}$ and $\mathrm{C}_{5} \mathrm{D}_{5} \mathrm{~N}$; unequivocally attribution of NMR signals was attained with 2D-NMR experiments COSY and NOESY.

$\mathrm{UV}-\mathrm{V}$ is spectra were recorded in DMSO solutions on a UV-2501-PC Shimadzu spectrophotometer using quartz cells with 1 $\mathrm{cm}$ of optical length. MALDI-MS spectra were acquired from a MALDI/TOF/TOF 4800 Applied Biosystems MDS Sciex using $\mathrm{CH}_{2} \mathrm{Cl}_{2}$ or $\mathrm{CH}_{3} \mathrm{OH}$, with and without matrix. ESI mass spectra were acquired with a Micromass Q-Tof 2 (Micromass, 
Manchester, UK), operating in the positive ion mode, equipped with a Z-spray source, an electrospray probe and a syringe pump. ESI ${ }^{+}$ HR-MS were recorded on a VG Autospec M in University of Vigo, Spain.

\section{SYNTHESIS OF THE CORROLE MACROCYCLES}

Synthesis of 5,10,15-tris[4-(pyridin-4ylsulphanyl)-2,3,5,6-tetrafluorophenyl]corrolategallium(III)pyridine (2a): In a sealed reaction vessel $10.0 \mathrm{mg}$ of $\mathbf{1}(10.6 \mu \mathrm{mol})$ were added to $12 \mathrm{mg}$ of 4 -mercaptopyridine (10 eq., $0.11 \mathrm{mmol}$ ) in the presence of $\mathrm{K}_{2} \mathrm{CO}_{3}$ in excess $(60 \mathrm{mg})$, using $0.3 \mathrm{~mL}$ of dried DMSO as solvent. The reaction was carried out at room temperature under stirring and $\mathrm{N}_{2}$ atmosphere for $1 \mathrm{~h} 30 \mathrm{~min}$. The reactional mixture was neutralized with aqueous citric acid solution followed by extraction of the organic phase with $\mathrm{CH}_{2} \mathrm{Cl}_{2}$, and then dried with anhydrous sodium sulphate. The crude mixture was then separated by column flash chromatography using as eluent a mixture of hexane:ethyl acetate:pyridine (150:50:1). Compound 2a was obtained in $27 \%$ yield (3.0 mg).

${ }^{1} \mathbf{H}$ NMR $\left(\mathrm{CDCl}_{3}\right.$ and $\left.\mathrm{C}_{5} \mathrm{D}_{5} \mathrm{~N} ; 300,13 \mathrm{MHz}\right)$ : $\delta 9.31$ (d, 2H, J 4.1 Hz, H-2,18); 8.98 (d, 2H, J $4.6 \mathrm{~Hz}, \mathrm{H}-7,13) ; 8.91$ (d, 2H, J $4.1 \mathrm{~Hz}, \mathrm{H}-3,17)$; 8.77 (d, 2H, J 4.6 Hz, H-8,12); 8.60 - 8.64 (m, $6 \mathrm{H}, \mathrm{H}-\mathrm{Ar}) ; 7.37-7.33$ (m, 6H, H-Ar) ${ }^{19} \mathbf{F}$ NMR $\left(\mathrm{CDCl}_{3}\right.$ and $\left.\mathrm{C}_{5} \mathrm{D}_{5} \mathrm{~N} ; 282.38 \mathrm{MHz}\right): \delta-155.18$ to $-155.50\left(\mathrm{~m}, 6 \mathrm{~F}, \mathrm{~F}_{\text {ortho }}\right) ;-159.03$ to $-159.27(\mathrm{~m}, 6 \mathrm{~F}$, $\left.\mathrm{F}_{\text {meta }}\right) \mathrm{UV}$-Vis in DMSO $\lambda_{\max }(\log \varepsilon): 436$ (5.22), 575 (4.08) 607 (4.39). HR-MS ESI ${ }^{+} \mathrm{m} / z$ : calcd. for $\mathrm{C}_{52} \mathrm{H}_{21} \mathrm{~F}_{12} \mathrm{GaN}_{7} \mathrm{~S}_{3} 1136.0079[\mathrm{M}-\mathrm{py}+\mathrm{H}]^{+}$, found 1136.0079 .

Synthesis of 5,10,15-tris[4-(pyridin2-ylsulfanyl)-2,3,5,6-tetrafluorophenyl]correlategallium(III)pyridine (3a): In a sealed reaction vessel $10.0 \mathrm{mg}$ of $\mathbf{1}(10.6 \mu \mathrm{mol})$ were added to $12 \mathrm{mg}$ of 2 -mercaptopyridine (10 eq., $0.11 \mathrm{mmol}$ ) in the presence of $\mathrm{K}_{2} \mathrm{CO}_{3}$ in excess $(60 \mathrm{mg})$, using
$0.3 \mathrm{~mL}$ of dried DMSO as solvent. The reaction was carried out at room temperature under stirring and $\mathrm{N}_{2}$ atmosphere for $3 \mathrm{~h} 30 \mathrm{~min}$. The reactional mixture was neutralized with aqueous citric acid solution followed by extraction of the organic phase with $\mathrm{CH}_{2} \mathrm{Cl}_{2}$, and then dried with anhydrous sodium sulphate. The crude mixture was then separated by column flash chromatography using as eluent a mixture of hexane:ethyl acetate:pyridine (150:50:1). Compound 3a was obtained in 43\% yield (4.8 mg).

${ }^{1} \mathbf{H}$ NMR $\left(\mathrm{CDCl}_{3}\right.$ and $\left.\mathrm{C}_{5} \mathrm{D}_{5} \mathrm{~N} ; 300,13 \mathrm{MHz}\right)$ : ठ 9.27 (d, 2H, J 4.1 Hz, H-2, 18); 9.01 (d, 2H, J $4.6 \mathrm{~Hz}, \mathrm{H}-7,13$ or H-8, 12); 8.92 (d, 2H, J 4.1 Hz, $\mathrm{H}-3,17) ; 8.79$ (d, 2H, J 4.6 Hz, H-7, 13 or H-8, 12); 8.59-8.56 (m, 3H, H-Ar); 8,55-8,51 (m, 3H, H-Py); 7.75-7.69 (m, 3H, H-Ar); 7.65-7.62 (m, 2H, H-Py); 7.45 (m, 3H, H-Ar); 7.27-7.19 (m, 3H, H-Ar). ${ }^{19} \mathbf{F}$ NMR $\left(\mathrm{CDCl}_{3}\right.$ and $\left.\mathrm{C}_{5} \mathrm{D}_{5} \mathrm{~N}, 282.38 \mathrm{MHz}\right)$ : $\delta-154.5$ (dd, 4F, J 25.4 Hz, $\mathrm{F}_{\text {ortho }}$ ); $\delta-154.6$ (dd, 2F, J 25.4 $\left.\mathrm{Hz}, \mathrm{F}_{\text {ortho }}\right) ; \delta-159.3$ to $-159.5\left(\mathrm{~m}, 6 \mathrm{~F}, \mathrm{~F}_{\text {meta }}\right)$. UVVis in DMSO $\lambda_{\max }(\log \varepsilon)$ : 428 (5.30) 596 (4.34). MS MALDI-TOF m/z 1135 [M-py] $]^{+\bullet}$ m/z 1116 $[(\mathrm{M}-\mathrm{py})-\mathrm{HF}+\mathrm{H}]^{+}, \mathrm{m} / \mathrm{z} 1096[(\mathrm{M}-\mathrm{py})-2 \mathrm{HF}+\mathrm{H}]^{+}, m / z$ 1076 [(M-py)-3HF+H] .

General procedure for the cationization of the neutral corrole macrocycles: In a reaction sealed vial, it was added to the neutral corrole derivatives dissolved in dried DMF, $\mathrm{CH}_{3} \mathrm{I}$ in large excess; then, the resulting mixture was maintained at $40{ }^{\circ} \mathrm{C}$ overnight and under stirring. After this period the reaction vial was cooled down to 0 ${ }^{\circ} \mathrm{C}$ (using ice) and it was added diethyl ether in order to promote the precipitation of the alkylated compound. The resulting precipitate was filtered and washed several times with cool diethyl ether. The solid was dissolved in a methanol:water solution and then precipitated in a metanol:diethyl ether solution.

Synthesis of 5,10,15-tris [4-(1-methylpyridin4-ylsulfanyl)-2,3,5,6-tetrafluoro-phenyl] correlategallium(III)(pyridine) tri-iodide ( $2 \mathrm{~b})$ :In 
a reaction vial $18.2 \mathrm{mg}(0.016 \mathrm{mmol})$ of corrole 2a and $2.0 \mathrm{~mL}(3.2 \mathrm{mmol})$ of $\mathrm{CH}_{3} \mathrm{I}$ were added to $3.0 \mathrm{~mL}$ of dried DMF. Following the conditions described in the general procedure compound $\mathbf{2 b}$ was obtained quantitatively.

${ }^{1} \mathrm{H}$ NMR $\left(\mathrm{CD}_{3} \mathrm{OD}\right.$ and $\left.\mathrm{C}_{5} \mathrm{D}_{5} \mathrm{~N} ; 300.13 \mathrm{MHz}\right)$ : $\delta 9.37$ (d, 2H, J 4.0 Hz, H-2,18); 9.20 (d, 2H, J $4.4 \mathrm{~Hz}, \mathrm{H}-7,13$ ); 9.07 (d, 2H, J 4.0 Hz, H-3,17); 9.00 (d, 2H, J 4.4 Hz, H-8,12); 8.85 (d, 6H, J 6.6 Hz, H-Ar); 8.23 (d, 6H, J 6.6 Hz, H-Ar); 4.42 (s, 9H, $3 \times \mathrm{CH}_{3}, \mathrm{H}-5$, 5 ", 5 ,"'). ${ }^{19} \mathbf{F}$ NMR ( $\mathrm{CD}_{3} \mathrm{OD}$ and $\left.\mathrm{C}_{5} \mathrm{D}_{5} \mathrm{~N} ; 282.38 \mathrm{MHz}\right): \delta-157.59$ to -157.85 $\left(\mathrm{m}, 6 \mathrm{~F}, \mathrm{~F}_{\text {ortho }}\right)$; -160.46 to $-160.79\left(\mathrm{~m}, 6 \mathrm{~F}, \mathrm{~F}_{\text {meta }}\right)$. UV-Vis in DMSO $\lambda_{\text {max }}(\log \varepsilon): 430(5.10), 577$ (4.67), 596 (4.51). HR-MS $\mathrm{ESI}^{+} \mathrm{m} / \mathrm{z}$ : calcd. for $\left[\mathrm{C}_{55} \mathrm{H}_{29} \mathrm{~F}_{12} \mathrm{GaN}_{7} \mathrm{~S}_{3}\right]^{3+} \cdot 589.53108[\mathrm{M}-\mathrm{py}-\mathrm{H}]^{2+}$, found 589.5311 .

Synthesis of 5,10,15-tris[4-(1-methylpyridin2-ylsulfanyl)-2,3,5,6-tetrafluoro-phenyl] corrolategallium(III)(pyridine) tri-iodide (3b): In a reaction vessel $18.2 \mathrm{mg}(0.016 \mathrm{mmol})$ of corrole $3 \mathbf{a}$ and $2.0 \mathrm{~mL}$ (3.2 mmol) of $\mathrm{CH}_{3} \mathrm{I}$ were added to $3.0 \mathrm{~mL}$ of dried DMF. Following the conditions described in the general procedure compound $\mathbf{3 b}$ was obtained quantitatively.

${ }^{1} \mathbf{H}$ NMR $\left(\mathrm{CD}_{3} \mathrm{OD}\right.$ and $\left.\mathrm{C}_{5} \mathrm{D}_{5} \mathrm{~N} ; 300.13 \mathrm{MHz}\right)$ : $\delta 9.39$ (d, J 4.0 Hz, H- $\beta$ ); $\delta 9.25$ (d, J 4.5 Hz, H- $\beta$ ); 9.14 - 9.11 (m, H- $\beta$ ); 9.05 (d, J 4.3 Hz, H-Ar); 8.95 (d, J 6.0 Hz, H-Ar); 8.66 - 8.61 (m, H-Ar); 8.55 (sl, H-Py); 8.50 - 8.47 (m, H-Ar); 8.31 (d, J 8.3 Hz, H-Ar); 8.06 - 8.01 (m, H-Ar); 7.87 (sl, H-Py); 7.70 (d, J 8.9 Hz, H-Ar); 7.55 - 7.5 (m, H-Ar); 7.46 (sl, H-Py); 4.69 (s, 6H, $\mathrm{CH}_{3}$ ); 4.08 (s, 3H, $\mathrm{CH}_{3}$ ). ${ }^{19} \mathbf{F}$ NMR $\left(\mathrm{CD}_{3} \mathrm{OD}\right.$ and $\left.\mathrm{C}_{5} \mathrm{D}_{5} \mathrm{~N} ; 282.38 \mathrm{MHz}\right) \delta-157.1$ to $-157.4\left(\mathrm{~m}, 6 \mathrm{~F}, \mathrm{~F}_{\text {ortho }}\right) ;-160.1$ to $-160.3(\mathrm{~m}, 6 \mathrm{~F}$, $\left.\mathrm{F}_{\text {meta }}\right)$. UV-Vis em DMSO $\lambda_{\text {max }}(\log \varepsilon): 433$ (5.24) 605 (4.47) MS ESI ${ }^{+}$m/z: 393.4 [M-py] ${ }^{3+}$.

\section{Determination of the Singlet Oxygen Generation}

Stock solutions of each PS at $0.1 \mathrm{mM}$ in DMF and a stock solution of 1,3-diphenylisobenzofuran
(DPBF) at $10 \mathrm{mM}$ in DMF were prepared. A mixture of $50 \mu \mathrm{M}$ of DPBF and $0.5 \mu \mathrm{M}$ of the PS derivative in DMF in glass cells $(2 \mathrm{~mL})$ was irradiated with a LED array at an irradiance of $9.0 \mathrm{~mW} \mathrm{~cm} \mathrm{c}^{-2}$. A LED square array ( 5 x 5 LEDs light sources) with an emission peak centered at $640 \mathrm{~nm}$ and a bandwidth at half maximum of $\pm 20 \mathrm{~nm}$ was constructed and used as light source. Irradiation was conducted at room temperature under stirring. The breakdown of DPBF, indicative of singlet oxygen production, was monitored by measuring the decreasing of the absorbance at $415 \mathrm{~nm}$ at irradiation intervals of 1 min for $10 \mathrm{~min}$.

\section{Biological assays}

Bacteria cells were conditioned at $-80{ }^{\circ} \mathrm{C}$ in $10 \%$ glycerol. Fresh cultures were maintained in solid BOSS at $4 \%$ (1\% peptone, $0.3 \%$ meat extract, $0.1 \%$ glycerol, $3 \% \mathrm{NaCl}, 1.5 \%$ agar, $\mathrm{pH}$ 7.3). For each assay, in asepsis, an isolated colony was inoculated in $30 \mathrm{~mL}$ of liquid BOSS medium for one day at $25{ }^{\circ} \mathrm{C}$ under stirring $(120 \mathrm{rpm})$. An aliquot of this culture was subcultivated $(240 \mu \mathrm{L})$ in $30 \mu \mathrm{L}$ of liquid BOSS medium and grown overnight at $25^{\circ} \mathrm{C}$ under stirring $(120 \mathrm{rpm})$ until an optical density of 1.0 was attained at $620 \mathrm{~nm}\left(\mathrm{DO}_{620} \approx 1.0\right)$, meaning around $10^{8}$ cells $/ \mathrm{mL}$.

\section{Bacterial strain and growth conditions}

The bacterial model used in this work was the marine bioluminescent bacterium Allivibrio fischeri (A. fischeri) ATCC 49387 (USA). Cells were stored at $-80{ }^{\circ} \mathrm{C}$ in $10 \%$ glycerol. Fresh plate cultures of A. fischeri were maintained in solid BOSS medium at $4{ }^{\circ} \mathrm{C}$ (BOSS medium: $1 \%$ peptone, $0.3 \%$ beef extract, $0.1 \%$ glycerol, $3 \% \mathrm{NaCl}, 1.5 \%$ agar, $\mathrm{pH}$ 7.3)]. A concentration of $20-40 \mathrm{~g} \mathrm{~L}^{-1}$ of $\mathrm{NaCl}$ is necessary to maintain the osmotic pressure of cells required to natural light emission to occur. Before each assay, one isolated colony was aseptically inoculated in $30 \mathrm{~mL}$ of liquid BOSS medium and 
it was allowed to grow for one day at $25{ }^{\circ} \mathrm{C}$ under stirring (120 rpm). An aliquot of this culture (240 $\mathrm{mL}$ ) was subcultured in $30 \mathrm{~mL}$ of BOSS medium and grew overnight at $25{ }^{\circ} \mathrm{C}$ under stirring (120 rpm) to reach an optical density $\left(\mathrm{OD}_{620}\right)$ of $\sim 1.0$, corresponding to $<10^{8}$ cells $\mathrm{mL}^{-1}$.

\section{Bioluminescence versus Colony forming units of} an overnight culture

The correlation between the colony-forming units (CFU) and the bioluminescence signal of $A$. fischeri was evaluated and a high correlation $(\mathrm{R}=0.99)$ between viable counts and the bioluminescence signal of overnight cultures was observed. It was used a luminometer $(0.5 \mathrm{~mL})$ (TD-20/20 Luminometer, Turner Designs, Inc., Madison, WI, USA) to determine the bioluminescence signal. Thus, the bioluminescence results reflect the viable bacterial abundance, allowing to obtain results in real time in a cost-effective way.

\section{Photosensitizer stock solutions}

Stock solutions of the photosensitizers used in the biological studies were prepared in dimethylsulfoxide (DMSO) at a concentration of $500 \mu \mathrm{mol} \mathrm{L}{ }^{-1}$, and diluted with phosphate buffered saline (PBS) to reach the final concentrations used in the photoinactivation experiments.

\section{Light source}

All the photoinactivation experiments were performed under white light from a compatible fibre optic probe $(400-800 \mathrm{~nm})$ attached to a $250 \mathrm{~W}$ quartz/halogen lamp (LumaCare ${ }^{\circledR}$, USA, model LC122) with an irradiance of $100 \mathrm{~mW} \mathrm{~cm}^{-2}$. All the irradiances were measured with a Power Meter Coherent FieldMaxII-Top combined with a Coherent PowerSens PS19Q energy sensor

\section{PDI experimental setup}

The assays were carried out by exposing the $A$. fischeri suspension to each PS added from the stock solution to achieve the final concentrations $(10$ and $20 \mu \mathrm{M})$. After the addition of the PS, all beakers were protected from accidental light exposure with an aluminium foil and preincubated for $15 \mathrm{~min}$ in the dark, under $100 \mathrm{rpm}$. After this period, the irradiation was conducted under white light. During the irradiation, the inactivation kinetics was assessed by periodically collecting aliquots of the cell suspensions for bioluminescence signal determinations in the luminometer during the irradiation period ( 0 and $10,20,30,45,60,75,90$ and 120 min irradiation). For each PS and concentration, three independent experiments in duplicate were conducted and the final results were expressed as the overall average. The survival curves were constructed by plotting bioluminescence against irradiation time ( $\mathrm{min}$ ).

\section{RESULTS AND DISCUSSION}

The access to the cationic derivatives involved, in a first step, the synthesis of the corresponding neutral corroles 2a and 3a via nucleophilic substitution of the para-fluorine atoms in the pentafluorophenyl groups of the gallium(III) complex of 5,10,15-tris(pentafluorophenyl)corrole $\mathbf{1}$ (Gross et al. 1999) using the adequate pyridine derivatives, 4-mercaptopyridine and 2-mercaptopyridine (Figure 1).

This approach, although largely explored to functionalize the analogue 5,10,15,20-tetrakis(p entafluorophenyl)porphyrin, (Costa et al. 2011b, Castro et al. 2017) has also been envisaged for the functionalization of corrole $\mathbf{1}$ (Cardote et al. 2012, Hori and Osuka 2010, Barata et al. 2013). After a systematic evaluation of the experimental conditions, namely solvent type, temperature, base, number of equivalents of the nucleophile, it was verified that the best yields of the tris-substituted 


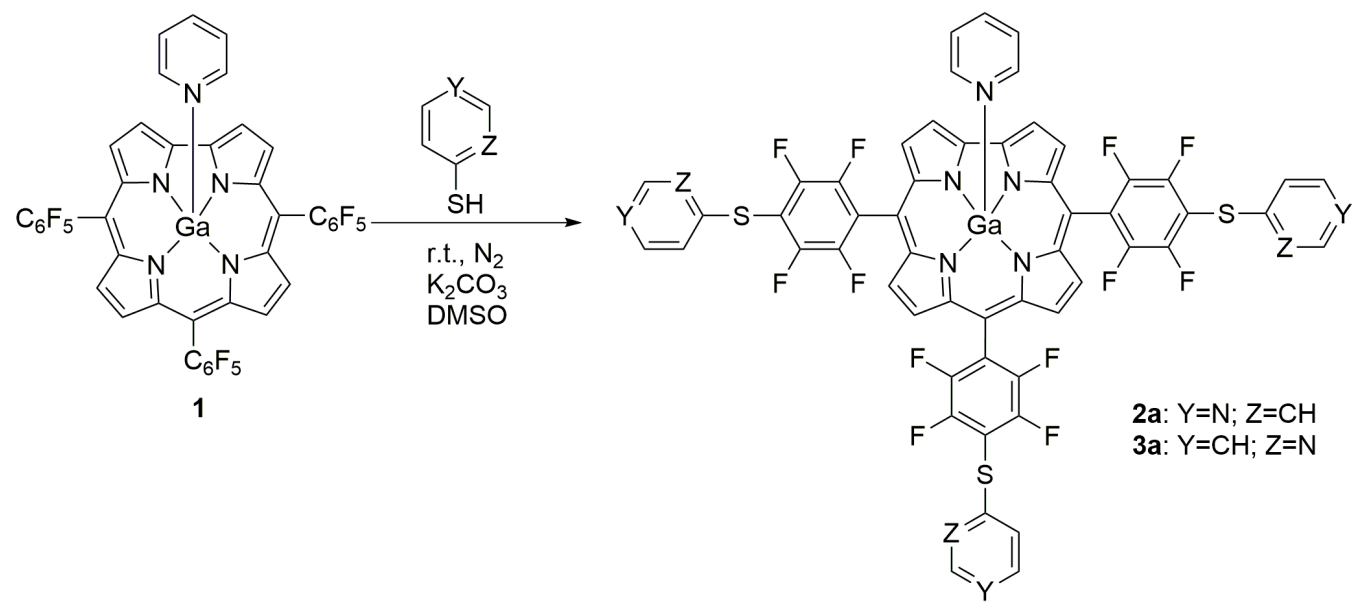

Figure 1 - Reaction of gallium(III) complex of 5,10,15-tris(pentafluorophenyl)corrole 1 with adequate pyridine derivatives.

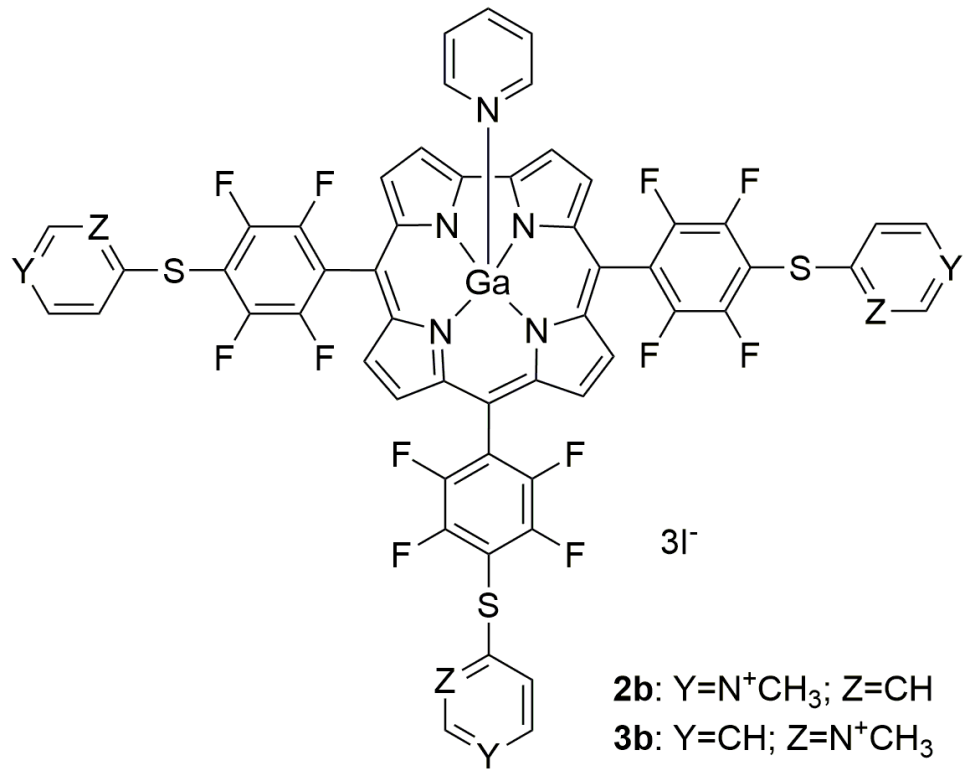

Figure 2 - Structures of the 5,10,15-tris[2,3,5,6-tetrafluoro-4-(1methylpyridinium-4-sulfanyl)phenyl]corrolatogallium(III)(pyridine) triiodide $\mathbf{2 b}$ and 5,10,15-tris[2,3,5,6-tetrafluoro-4-(1-methylpyridinium-2sulfanyl)phenyl]corrolatogallium(III)(pyridine) tri-iodide $\mathbf{3 b}$.

derivatives were obtained when the reactions were performed at room temperature under nitrogen, in DMSO and using $\mathrm{K}_{2} \mathrm{CO}_{3}$ as the base. The coupling reactions of 2- or 4-mercaptopyridines were performed at room temperature in the presence of ten equivalents of the nucleophile. In both cases, in the range $1 \mathrm{~h} 30 \mathrm{~min}-3 \mathrm{~h} 30 \mathrm{~min}$, the TLC analysis revealed the formation of an important product that was identified, after workup and chromatographic purification of the crude material, as being the expected tris-substituted derivatives $\mathbf{2 a}(27 \%)$ and 3a $(43 \%)$.

The quaternization of the pyridyl units in corroles 2a and 3a was performed in DMF, with methyl iodide at $40{ }^{\circ} \mathrm{C}$ overnight, affording the expected tricationic derivatives $\mathbf{2} \mathbf{b}$ and $\mathbf{3 b}$ in quantitative yields after precipitation with ethyl ether (Figure 2). 


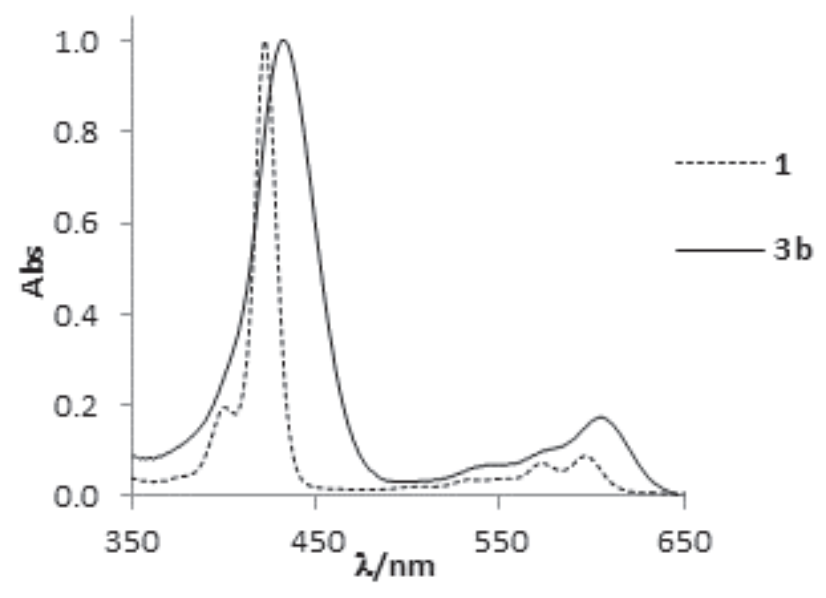

Figure 3 - Normalized UV-Vis spectra of compounds $\mathbf{1}$ and 3b in DMSO.

All compounds were characterized by ${ }^{1} \mathrm{H}$ and ${ }^{19}$ F NMR spectroscopy and mass spectrometry. The spectroscopic data of all new derivatives were in accordance with the proposed structures. The trisubstituted derivatives were easily identified by the presence at ${ }^{19} \mathrm{~F}$ NMR spectra of only two sets of signals due to the ortho and meta fluorine atoms with the complete disappearance of the signals due to the resonance of the para-fluorine atoms. The cationization of the pyridyl groups was confirmed by the appearance of the characteristic singlets due to the resonance of the methyl groups in the ${ }^{1} \mathrm{H}$ spectra of compounds $\mathbf{2 b}, \mathbf{3 b}$. All attempts to reach the corresponding tri-substituted free-bases from 5,10,15-tris(pentafluorophenyl)corrole afforded such derivatives in very low yields $(<10 \%)$. The absorption spectra of all compounds in DMSO are dominated by an intense absorption band around $430 \mathrm{~nm}$ (Soret band) and the less intense Q-bands between 540-610 nm. As an example, in Fig. 3 shows the UV-Vis spectrum of the derivative $\mathbf{3 b}$ and the one due to the starting corrole $\mathbf{1 .}$

Considering the potential application of the new corroles as photosensitizers it was evaluated their ability to generate singlet oxygen. This was qualitatively evaluated by monitoring the photodegradation of 1,3-diphenylisobenzofuran (DPBF) and the data obtained are displayed in Fig.
4. The results show that the DPBF photodegradation was, in general, enhanced in the presence of the corrole. All the corrole derivatives (2a, 3a, 2b and $\mathbf{3 b}$ ) although with different efficiency, proved to be able to produce singlet oxygen. The DFBF decomposition caused by the neutral derivatives 2a and 3a is higher than that caused by the cationic derivatives $\mathbf{2} \mathbf{b}$ and $\mathbf{3 b}$. The results show also that the para-substituted corrole 2a has a higher efficiency to generate singlet oxygen than the corresponding ortho-substituted corrole $\mathbf{3 a}$.

\section{Antibacterial Activity}

To assess the antibacterial effect of the cationic corroles $\mathbf{2} \mathbf{b}$ and $\mathbf{3 b}$, it was used a light emitting Gram-negative bacterium Allivibrio fischeri ( $A$. fischeri) under irradiation with white light (400$800 \mathrm{~nm}$ ), at an irradiance of $100 \mathrm{~mW} \mathrm{~cm}^{-2}$ for 120 min (total light dose of $0.72 \mathrm{~kJ} \mathrm{~cm}^{-2}$ ). The light output from these bioluminescent bacteria is a highly sensitive marker of their metabolic activity and it can be easily read in a luminometer with a strong correlation between bioluminescence (measured in relative light units, RLU) and viable cell counts. (Tavares et al. 2010, Alves et al. 2011a, b, Mesquita et al. 2014b). The efficiency of the

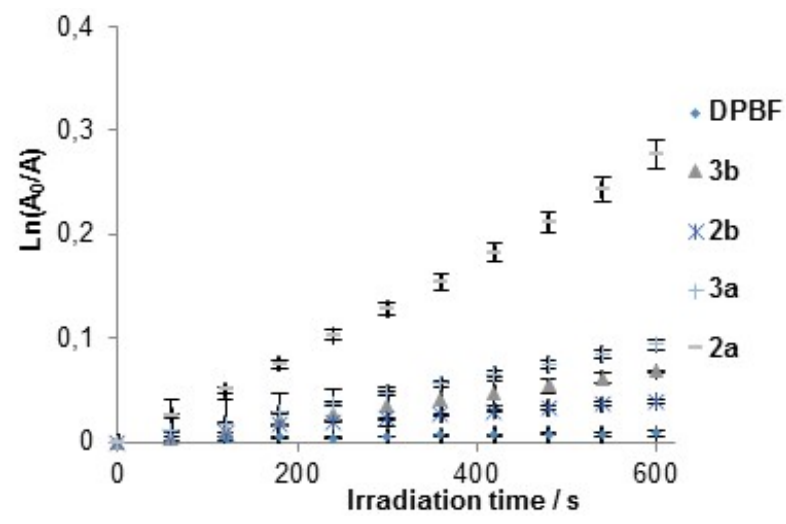

Figure 4 - Time dependent photodecomposition of DPBF (50 $\mathrm{mM}$ ) photosensitized by corroles derivatives $\mathbf{2} \mathbf{a}, \mathbf{b}$ and $\mathbf{3} \mathbf{a}, \mathbf{b}$ in DMF upon irradiation with a LED array with an emission peak centred at $640 \mathrm{~nm}$ and a bandwidth at half maximum of \pm 20 $\mathrm{nm}\left(9.0 \mathrm{~mW} \mathrm{~cm}^{-2}\right)$ with or without PS $(0.5 \mu \mathrm{M})$. 


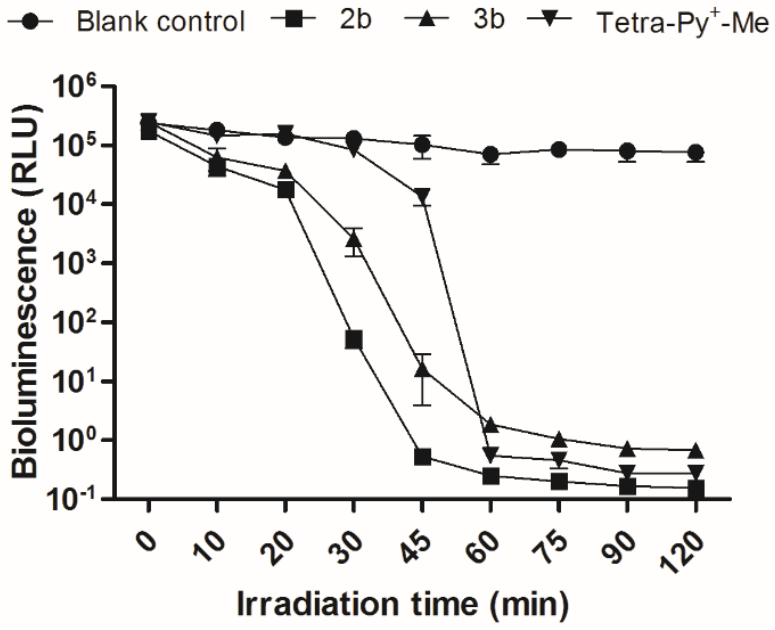

Figure 5 - Bioluminescence monitoring of $A$. fischeri treated with $10 \mathrm{mM}$ of cationic PSs $\mathbf{2 b}$ and $\mathbf{3 b}$ and Tetra-Py ${ }^{+}-\mathbf{M e}$ after irradiation with white light (400-800 nm) at an irradiance of $100 \mathrm{~mW} \mathrm{~cm}^{-2}$ during $120 \mathrm{~min}$. Each value represents the mean \pm standard deviation of three independent experiments, with two replicates each. Error bars indicate the standard deviation.

cationic corroles $\mathbf{2} \mathbf{b}$ and $\mathbf{3 b}$ was compared with that of 5,10,15,20-tetrakis(1-methylpyridinium-4yl)porphyrin tetra-iodide (Tetra-Py $\left.{ }^{+}-\mathbf{M e}\right)$ which has been extensively studied in bacterial PDI studies (Almeida et al. 2011, Pereira et al. 2014). The kinetics of photoinactivation of $A$. fischeri was evaluated at two different corrole concentrations (20 and $10 \mu \mathrm{M})$. The significance of the difference in bacterial inactivation among the different compounds was assessed by the Kruskal-Wallis test along with post-hoc tests, using IBM SPSS Statistics for Windows, Version 20.0 (IBM Corp. Armonk, NY). A value of $p<0.05$ was considered significant.

At $20 \mu \mathrm{M}$, corroles $\mathbf{2} \mathbf{b}$ and $\mathbf{3 b}$ were able to reduce $A$. fischeri bioluminescence of $>6 \log _{10}$ RLU after 30 min of irradiation $\left(0.18 \mathrm{~kJ} \mathrm{~cm}^{-2}\right)$ and the results were not significantly different from the pattern of Tetra-Py ${ }^{+}-\mathbf{M e}$ (data not shown).

At the concentration of $10 \mathrm{mM}$ (Fig.5), the limit of detection ( $>6 \log _{10}$ RLU reduction) was reached for corrole $\mathbf{2 b}$ after $45 \min \left(0.27 \mathrm{~kJ} \mathrm{~cm}^{-}\right.$ ${ }^{2}$ ) of irradiation. At this irradiation time, PDI with
Tetra-Py ${ }^{+}-\mathbf{M e}$ was significantly different from the corroles $\mathbf{2 b}$ and $\mathbf{3 b}(p=0.046)$ (figure 5). However the same reduction on $A$. fischeri was attained with corrole $\mathbf{3 b}$ and Tetra-Py ${ }^{+}-\mathbf{M e}$ after $60 \mathrm{~min}$ of irradiation $(p>0.05)$. It is worth to refer that all the studied compounds did not exhibit toxicity against the bacterial strain in the absence of light (dark controls) at the tested concentrations or by direct exposure to light in the absence of PS (blank control).

Since corroles usually show single properties when compared with porphyrins, we decided to evaluate if the neutral precursors $\mathbf{2 a}$ and $\mathbf{3 a}$ were able to photoinactivate A. fischeri (Fig. 6). The non-cationic corroles 2a, 3a and 5,10,15,20-tetra(4pyridyl)porphyrin were not able to efficiently affect the Gram-negative strain by irradiation which is in accordance with literature (Carvalho et al. 2007, Mesquita et al. 2014a). It is well established that the efficient photoinactivation of Gram-negative bacteria requires the presence of positively charged PS at physiological $\mathrm{pH}$ or the presence of

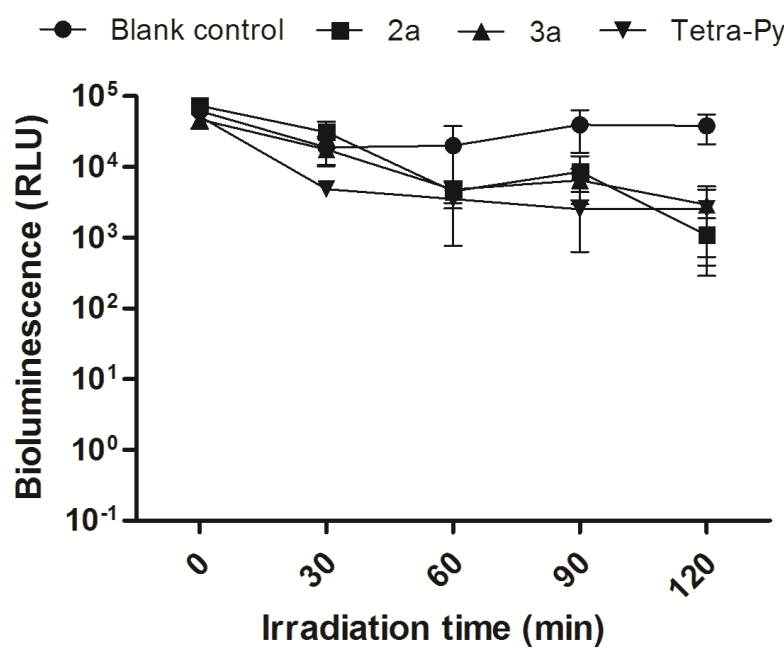

Figure 6 - Bioluminescence monitoring of $A$. fischeri treated with $10 \mathrm{mM}$ of neutral corroles $\mathbf{2} \mathbf{a}$ and $\mathbf{3} \mathbf{a}$ and 5,10,15,20-tetra(4pyridyl)porphyrin (Tetra-Py) after irradiation with white light (400-800 $\mathrm{nm}$ ) at an irradiance of $100 \mathrm{~mW} \mathrm{~cm}^{-2}$ during $120 \mathrm{~min}$. Each value represents the mean \pm standard deviation of three independent experiments, with two replicates each. Error bars indicate the standard deviation. 
membrane disruptors such as EDTA or polymyxin B nonapeptide (Costa et al. 2011a, Malik et al. 1992, Preuß et al. 2012).

\section{CONCLUSIONS}

In this study, it is described the access to positively charged metallocorroles and their potential application as antibacterial agents. Contrary to the neutral derivatives, both cationic corrole derivatives exhibit ability to photoinactivate the Gram-negative bacterium $A$. fischeri under white light irradiation $\left(100 \mathrm{~mW} \mathrm{~cm}^{-2}\right)$ at all tested concentrations without demonstrating any dark toxicity. Corrole $\mathbf{2 b}$ demonstrated at the lower tested dose, notable efficiency when compared with the well-known TetraPy ${ }^{+}-\mathbf{M e}$, achieving total photoinactivation ( $>$ $6 \log _{10}$ RLU reduction) after 45 min of irradiation. This preliminary study highlights the properties of cationic corroles for being used in antimicrobial photoinactivation.

\section{ACKNOWLEDGMENTS}

The authors are thankful to the University of Aveiro, to FCT/MEC for the financial support to the QOPNA Research Unit (FCT UID/ QUI/00062/2013) and Centre for Environmental and Marine Studies (CESAM) unit (project Pest-C/ MAR/LA0017/2013), through national founds and, where applicable, co-financed by the FEDER, within the PT2020 Partnership Agreement, and also to the Portuguese NMR Network. E.A. and J.F.B.B. also thank FCT for their PhD (SFRH/BD/41806/2007) and Post-Doc (SFRH/BPD/63237/2009) grants, respectively.

\section{REFERENCES}

AGADJANIAN H, MA J, RENTSENDORJ A, VALLURIPALLI V, HWANG JY, MAHAMMED A, FARKAS DL, GRAY HB, GROSS Z AND MEDINAKAUWE LK. 2009. Tumor detection and elimination by a targeted gallium corrole. P Natl Acad Sci USA 106: 61056110 .
ALMEIDA A, CUNHA Â, FAUSTINO MAF, TOMÉ AC AND NEVES MGPMS. 2011. in Photodynamic inactivation of microbial pathogens: medical and environmental applications, Royal Society of Chemistry, Cambridge, 83.

ALMEIDA A, FAUSTINO MAF AND TOMÉ JPC. 2015. Photodynamic inactivation of bacteria: finding the effective targets. Future Med Chem 7: 1221-1224.

ALVES E, FAUSTINO MAF, TOMÉ JPC, NEVES MGPMS, TOMÉ AC, CAVALEIRO JAS, CUNHA A, GOMES NCM AND ALMEIDA A. 2011a. Photodynamic antimicrobial chemotherapy in aquaculture: photoinactivation studies of Vibrio fischeri. PLoS ONE 6: e209701-9.

ALVES E, COSTA L, CUNHA Â, FAUSTINO MAF, NEVES MGPMS AND ALMEIDA A. $2011 \mathrm{~b}$. Bioluminescence and its application in the monitoring of antimicrobial photodynamic therapy. Appl Microbiol Biotechnol 92: 1115-1128.

ALVES E, COSTA L, CARVALHO CMB, TOMÉ JPC, FAUSTINO MAF, NEVES MGPMS, TOMÉ AC, CAVALEIRO JAS, CUNHA Â AND ALMEIDA A. 2009. Charge effect on the photoinactivation of Gramnegative and Gram-positive bacteria by cationic mesosubstituted porphyrins. BMC Microbiol 9(70): 1-13.

ALVES E, FAUSTINO MAF, NEVES MGPMS, CUNHA A, TOME J AND ALMEIDA A. 2014a. An insight on bacterial cellular targets of photodynamic inactivation. Future Med Chem 6: 141-164.

ALVES E, RODRIGUES JMM, FAUSTINO MAF, NEVES MGPMS, CAVALEIRO JAS, LIN Z, CUNHA Â, NADAIS MH, TOMÉ JPC AND ALMEIDA A. 2014b. A new insight on nanomagnet-porphyrin hybrids for photodynamic inactivation of microorganisms. Dyes Pigments 110: 80-88.

ALVES E, FAUSTINO MAF, NEVES MGPMS, CUNHA $\hat{A}$, NADAIS H AND ALMEIDA A. 2015. Potential applications of porphyrins in photodynamic inactivation beyond the medical scope. J Photochem Photobiol C 22: 34-57.

AVIV-HAREL I AND GROSS Z. 2009. Aura of Corroles. Chem Eur J 15: 8382-8394.

BARATA JFB, DANIEL-DA-SILVAAL, NEVES MGPMS, CAVALEIRO JAS AND TRINDADE T. 2013. Corrolesilica hybrid particles: synthesis and effects on singlet oxygen generation. RSC Adv 3: 274-280.

BARATA JFB, NEVES MGPMS, FAUSTINO MAF AND CAVALEIRO JAS. 2017. Strategies for corrole functionalization. Chem Rev 117: 3192-3253.

BARATA JFB, PINTO RJB, SERRA VIRCV, SILVESTRE AJD, TRINDADE T, NEVES MGPMS, CAVALEIRO JAS, DAINA S, SADOCCO P AND FREIRE CSR. 2016. Fluorescent Bioactive Corrole Grafted-Chitosan Films. Biomacromolecules 17: 1395-1403.

BARATA JFB, SANTOS CIM, NEVES MGPMS, FAUSTINO MAF AND CAVALEIRO JAS. 2014 
Functionalization of corroles. Top Heterocycl Chem 33: 79-142.

BARATA JFB, ZAMARRON A, NEVES MGPMS, FAUSTINO MAF, TOME AC, CAVALEIRO JAS, RÖDER B, JUARRANZ A AND SANZRODRIIGUEZ F. 2015. Photodynamic effects induced by meso-tris(pentafluorophenyl)corrole and its cyclodextrin conjugates on cytoskeletal components of HeLa cells. Eur J Med Chem 92: 135-144.

BATALHA PN ET AL. 2015. Synthesis of new porphyrin/4quinolone conjugates and evaluation of their efficiency in the photoinactivation of Staphylococcus aureus. RSC Adv 5: 71228-71239.

BONNETT R. 2000. Chemical aspects of photodynamic therapy. Ed. Gordon Breach Science, Amsterdam, Netherlands.

CARDOTE TAF, BARATA JFB, FAUSTINO MAF, PREUSS A, NEVES MGPMS, CAVALEIRO JAS, RAMOS CIV, SANTANA-MARQUES MGO AND RÖDER B. 2012. Pentafluorophenylcorrole-D-galactose conjugates. Tetrahedron Lett 53: 6388-6393.

CARVALHO CMB ET AL. 2009. Antimicrobial photodynamic activity of porphyrin derivatives: potential application on medical and water disinfection. J Porphyrins Phthalocyanines 13: 574-577.

CARVALHO CMB ET AL. 2010. Functional Cationic Nanomagnet-Porphyrin Hybrids for the Photoinactivation of Microorganisms. ACS Nano 4: 7133-7140.

CARVALHO CMB ET AL. 2007. Photoinactivation of bacteria in wastewater by porphyrins: Bacterial $\beta$-galactosidase activity and leucine-uptake as methods to monitor the process. J Photochem Photobiol B 88: 112118.

CASTRO KADF ET AL. 2017. Control of Listeria innocua biofilms by biocompatible photodynamic antifouling chitosan based materials. Dyes Pigments 137: 265-276.

COSTA DCS, GOMES MC, FAUSTINO MAF, NEVES MGPMS, CUNHA A, CAVALEIRO JAS, ALMEIDA A AND TOMÉ JPC. 2012. Comparative photodynamic inactivation of antibiotic resistant bacteria by first and second generation cationic photosensitizers. Photochem Photobiol Sci 11: 1905-1913.

COSTA JIT, TOMÉ AC, NEVES MGPMS AND CAVALEIRO JAS. 2011b. 5,10,15,20-tetrakis(penta fluorophenyl)porphyrin: a versatile platform to novel porphyrinic materials. J Porphyrins Phthalocyanines 15: 1116-1133.

COSTA L, FAUSTINO MAF, TOMÉ JPC, NEVES MGPMS, TOMÉ AC, CAVALEIRO JAS, CUNHA Â AND ALMEIDA A. 2013. Involvement of type I and type II mechanisms on the photoinactivation of non-enveloped DNA and RNA bacteriophages. J Photochem Photobiol B 120: $10-16$.

COSTA L, TOMÉ JPC, NEVES MGPMS, TOMÉ AC, CAVALEIRO JAS, FAUSTINO MAF, CUNHA Â, GOMES NCM AND ALMEIDA A. 2011a. Evaluation of resistance development and viability recovery by a non- enveloped virus after repeated cycles of aPDT. Antiviral Res 91: 278-282.

DAHL TA, MIDDEN WR AND HARTMAN PE. 1989. Comparison of killing of gram-negative and gram-positive bacteria by pure singlet oxygen. J Bacteriology 171: 21882194.

DEI D, CHITI G, DE FILIPPIS MP, FANTETTI L, GIULIANI F, GIUNTINI F, SONCIN M, JORI G AND RONCUCCI G. 2006. Phthalocyanines as photodynamic agents for the inactivation of microbial pathogens. J Porphyrins Phthalocyanines 10: 147-159.

ERGAIEG K, CHEVANNE M, CILLARD J AND SEUX R. 2008. Involvement of both Type I and Type II mechanisms in Gram-positive and Gram-negative bacteria photosensitization by a meso-substituted cationic porphyrin. Solar Energy 82: 1107-1117.

GOMES MC, SILVA S, FAUSTINO MAF, NEVES MGPMS, ALMEIDA A, CAVALEIRO JAS, TOMÉ, JPC AND CUNHA Â. 2013. Cationic galactoporphyrin photosensitisers against UV-B resistant bacteria: Oxidation of lipids and proteins by ${ }^{1} \mathrm{O}_{2}$. Photochem Photobiol Sci 12: 262-271.

GROSS Z, GALILI N AND SALTSMAN I. 1999. The first direct synthesis of corroles from pyrrole. Angew Chem Int Ed 38: 1427-1429.

HORI T AND OSUKA A. 2010. Nucleophilic Substitution Reactions of meso-5,10,15-Tris(pentafluorophenyl) corrole; Synthesis of ABC-Type Corroles and CorroleBased Organogels. Eur J Org Chem 2379-2386.

HWANG JY, LUBOW DJ, SIMS JD, GRAY HB, MAHAMMED A, GROSS Z, MEDINA-KAUWE LK AND FARKAS DL. 2012. Investigating photoexcitationinduced mitochondrial damage by chemotherapeutic corroles using multimode optical imaging. J Biomed Optics 17: 015003-1.

IGLESIAS BA, BARATA JFB, PEREIRA PMR, GIRAO H, FERNANDES R, TOME JPC, NEVES MGPMS AND CAVALEIRO JAS. 2015. New platinum(II)bipyridyl corrole complexes: Synthesis, characterization and binding studies with DNA and HSA. J Inorg Biochem 153: 32-41.

JORI G AND BROWN S. B. 2004. Photosensitized inactivation of microorganisms. Photochem Photobiol Sci. 3: 403-405.

LIM P, MAHAMMED A, OKUN Z, SALTSMAN I, GROSS Z, GRAY HB AND TERMINI J. 2012. Differential Cytostatic and Cytotoxic Action of Metallocorroles against Human Cancer Cells: Potential Platforms for Anticancer Drug Development. Chem Res Toxicol 25: 400-409.

LOURENÇO LMO, SOUSA A, GOMES MC, FAUSTINO MAF, ALMEIDA A, SILVA AMS, NEVES MGPMS, CAVALEIRO JAS, CUNHA A AND TOMÉ JPC. 2015. Inverted methoxypyridinium phthalocyanines for PDI of pathogenic bacteria Photochem Photobiol Sci 14: 1853-1863.

MAISCH T. 2009. A new strategy to destroy antibiotic resistant microorganisms: antimicrobial photodynamic treatment. Mini Rev- Med Chem 9: 974-983. 
MALIK Z, LADAN HAND NITZAN Y. 1992. Photodynamic inactivation of Gram-negative bacteria: problems and possible solutions. J Photochem Photobiol B 14: 262-266.

MARCIEL L, TELES L, MOREIRA B, PACHECO M, LOURENÇO LMO, NEVES MGPMS, TOMÉ JPC, FAUSTINO MAF AND ALMEIDA A. 2017. An effective and potentially safe blood disinfection protocol using tetrapyrrolic photosensitizers. Future Med Chem 9: 365-379.

MASIERA N, BOJARSKA A, GAWRYSZEWSKA I, SADOWY E, HRYNIEWICZ W AND WALUK J. 2017. Antimicrobial photodynamic therapy by means of porphycene photosensitizers. J Photochem Photobiol B 174: 84-89.

MESQUITA MQ, MENEZES JCJMDS, NEVES MGPMS, TOMÉ AC, CAVALEIRO JAS, CUNHA Â, ALMEIDA A, HACKBARTH S, RÖDER B. AND FAUSTINO MAF. 2014a. Photodynamic inactivation of bioluminescent Escherichia coli by neutral and cationic pyrrolidine-fused chlorins and isobacteriochlorins. Bioorg Med Chem Lett 24: 808-812.

MESQUITA MQ ET AL. 2014b. Pyrrolidine-fused chlorin photosensitizer immobilized on solid supports for the photoinactivation of Gram negative bacteria. Dyes Pigments 110: 123-133.

MOURA NMM, RAMOS CIV, LINHARES I, SANTOS SM, FAUSTINO MAF, ALMEIDA A, CAVALEIRO JAS, AMADO FML, LODEIRO C AND NEVES MGPMS. 2016. Synthesis, characterization and biological evaluation of cationic porphyrin-terpyridine derivatives. RSC Adv 6: 110674-110685.

PEREIRA MA, FAUSTINO MAF, TOMÉ JPC, NEVES MGPMS, TOMÉ AC, CAVALEIRO JAS, CUNHA Â AND ALMEIDA A. 2014. Influence of external bacterial structures on the efficiency of photodynamic inactivation by a cationic porphyrin. Photochem Photobiol Sci 13: 680690.

PEREIRA JB, CARVALHO EFA, FAUSTINO MAF, FERNANDES R, NEVES MGPMS, CAVALEIRO JAS, GOMES NCM, CUNHA A, ALMEIDA A AND TOMÉ JPC. 2012. Phthalocyanine Thio-Pyridinium Derivatives as Antibacterial Photosensitizers. Photochem Photobiol 88: 537-547.

POHL J, SALTSMAN I, MAHAMMED A, GROSS Z AND RÖDER B. 2014. Inhibition of green algae growth by corrole-based photosensitizers. J Appl Microbiol 118: 305-312.

PREUSS A, SALTSMAN I, MAHAMMED A, PFITZNER M, GOLDBERG I, GROSS Z AND RÖDER B. 2014. Photodynamic inactivation of mold fungi spores by newly developed charged corroles. J Photochem Photobiol B 133: 39-46.

PREUSS A, ZEUGNER L, HACKBARTH S, FAUSTINO MAF, NEVES MGPMS, CAVALEIRO JAS AND RÖDER B. 2013. Photoinactivation of Escherichia coli (SURE2) without intracellular uptake of the photosensitizer. J Appl Microbiol 114: 36-43.

ROCHA DMGC, VENKATRAMAIAH N, GOMES MC, ALMEIDA A, FAUSTINO MAF, ALMEIDA PAZ FA, CUNHA A AND TOMÉ JPC. 2015. Photodynamic inactivation of Escherichia coli with cationic ammonium Zn(II) phthalocyanines. Photochem Photobiol Sci 14: 1872-1879.

RUIZ-GONZÁLEZ R, AGUT M, REDDI E AND NONELL S. 2015. A comparative study on two cationic porphycenes: Photophysical and antimicrobial photoinactivation evaluation. Int J Mol Sci 16: 27072-27086.

RYSKOVA L, BUCHTA V, KARASKOVA M, RAKUSAN J, CERNY J AND SLEZAK R. 2013. IN VITRO antimicrobial activity of light-activated phthalocyanines. Cent Eur J Biol 8: 168-177.

SIMÕES C, GOMES MC, NEVES MGPMS, CUNHA Â, TOMÉ JPC, TOMÉ AC, CAVALEIRO JAS, ALMEIDA A AND FAUSTINO MAF. 2016. Photodynamic inactivation of Escherichia coli with cationic mesotetraarylporphyrins - The charge number and charge distribution effects. Catal Today 266: 197-204.

TAVARES A ET AL. 2011. Mechanisms of photodynamic inactivation of a Gram-negative recombinant bioluminescent bacterium by cationic porphyrins Photochem Photobiol Sci 10: 1659-1669.

TAVARES A ET AL. 2010. Antimicrobial Photodynamic Therapy: Study of Bacterial Recovery Viability and Potential Development of Resistance after Treatment Marine Drugs 8: 91-105.

TEO RD, HWANG JY, TERMINI J, GROSS Z AND GRAY HB. 2017. Fighting Cancer with Corroles. Chem Rev 117: 2711-2729.

WAINWRIGHT M, MAISCH T, NONELL S, PLAETZER K, ALMEIDA A, TEGOS GP AND HAMBLIN MR. 2017. Photoantimicrobials - are we afraid of the light? Lancet Infect Dis 17: e49-e55.

XAVIER R, SANCHEZ-GARCÍA D, RUIZ-GONZALEZ R, DAI T, AGUT M, HAMBLIN MR AND NONELL S. 2010. Cationic Porphycenes as Potential Photosensitizers for Antimicrobial Photodynamic Therapy. J Med Chem 53: 7796-7803.

YIN R, AGRAWAL T, KHAN U, GUPTA GK, RAI V, HUANG YY, HAMBLIN, MR 2015. Antimicrobial photodynamic inactivation in nanomedicine: Small light strides against bad bugs. Nanomedicine 10: 2379-2404. 